\title{
An overlooked hotspot for birds in the Atlantic Forest
}

\author{
Vagner Cavarzere ${ }^{1}$; Ciro Albano ${ }^{2}$; Vinicius Rodrigues Tonetti ${ }^{3}$; José Fernando Pacheco ${ }^{4}$; Bret M. Whitney ${ }^{5}$ \& Luís Fábio Silveira ${ }^{6}$ \\ 1 Universidade Tecnológica Federal do Paraná (UTFPR). Santa Helena, PR, Brasil. ORCID: http://orcid.org/0000-0003-0510-4557. \\ E-mail:vagnera@utfpr.edu.br \\ 2 Brazil Birding Experts. Fortaleza, CE, Brasil. E-mail: cironebrazilbirding@gmail.com \\ 3 Universidade Estadual Paulista (UNESP), Instituto de Biociências, Departamento de Ecologia. Rio Claro, SP, Brasil. \\ ORCID: http://orcid.org/0000-0003-2263-5608. E-mail: vrtonetti@gmail.com \\ ${ }^{4}$ Comitê Brasileiro de Registros Ornitológicos (CBRO). Rio de Janeiro, RJ, Brasil. ORCID: http://orcid.org/0000-0002-2399-7662. \\ E-mail: jfpacheco@terra.com.br \\ ${ }^{5}$ Louisiana State University, Museum of Natural Science. Baton Rouge, Louisiana, Estados Unidos. \\ ORCID: http://orcid.org/0000-0001-8442-9370.E-mail: kite1173@gmail.com \\ ${ }^{6}$ Universidade de São Paulo (USP), Museu de Zoologia (MZUSP). São Paulo, SP, Brasil. ORCID: http://orcid.org/0000-0003-2576-7657. \\ E-mail: Ifs@usp.br
}

\begin{abstract}
Montane and submontane forest patches in the state of Bahia, Brazil, are among the few large and preserved Atlantic Forests remnants. They are strongholds of an almost complete elevational gradient, which harbor both lowland and highland bird taxa. Despite being considered a biodiversity hotspot, few ornithologists have surveyed these forests, especially along elevational gradients. Here we compile bird records acquired from systematic surveys and random observations carried out since the 1980s in a 7,500 ha private protected area: Serra Bonita private reserve. We recorded 368 species, of which 143 are Atlantic Forest endemic taxa. Some 16 and 13 species are threatened at the global and national levels, respectively. If one accounts for subspecies, the number of Brazilian threatened taxa raises to 21. Species composition differs between lower and higher elevations, in which case lowlands harbor Amazonia-related taxa, whereas highlands are the home of Atlantic Forestrelated taxa.
\end{abstract}

Key-Words. Aves; Bahia; Elevational gradient; Serra Bonita.

\section{INTRODUCTION}

The Atlantic Forest originally comprised 150 million hectares of vegetation in highly heterogeneous environmental conditions. Its forests (the predominant type of vegetation within the domain) extend into tropical and subtropical regions due to a wide latitudinal range $\left(c a .30^{\circ}\right)$. The structure of these forests is quite distinct as one leaves Brazilian eastern shores into the interior of the country mostly because of the decreased rainfall away from the coasts. Coastal areas receive as much as $4,000 \mathrm{~mm}$ of rain year-round, while inland forests receive ca. 1,000 mm/year (Câmara, 2005). These features, combined with elevational gradients, resulted in high diversity and endemism for several groups of plants and animals (Goerck, 1997; Myers et al., 2000; Silva \& Casteleti, 2005). Currently, most of the remaining lowland (below about 500 meters elevation) Atlantic Forest is represented by small $(<50 \mathrm{ha})$ and isolated fragments composed predominantly by secondary growth in early to medium stages of succession (Ribeiro et al., 2009). Large fragments almost entirely remained in locations where steep terrains made human occupation particularly difficult (Silva et al., 2007).

Among the largest and best-preserved blocks of Atlantic Forests are montane and submontane forests in northern Espírito Santo and southern Bahia, Brazil (Ribeiro et al., 2009). Land cover in the region is a mosaic of native forest patches and areas of shade cocoa plantations interspersed with low-yield pastures, small farms and large forestry properties, the latter established mainly in the last three decades. Southern Bahia is the country's main cocoa (Theobroma cacao) production area (Alger \& Caldas, 1996; May \& Rocha, 1996; Cerqueira Neto, 2012). Nearly $70 \%$ of its cocoa production originates from the agroforestry system locally known as cabruca (Araújo et al., 1998), in which the cocoa trees, introduced from the Brazilian Amazon in 1746 (see Pacheco et al., 1996) replace the original understory and grow under 
the shade of a layer of native canopy species. This scenario is alarming since cabruca these poorly studied systems harbor great numbers of forest specialists (Pardini et al., 2009), including the Pink-legged Graveteiro (Acrobatornis fonsecai), a new genus and species unknown to science until the 1990s (Pacheco et al., 1996).

However, both the cocoa agroforests as forest remnants are still under intense threat. A severe socioeconomic crisis, caused by the devastation of cocoa farming by the Witches' Broom Disease and the falling price of cocoa on the international market, has triggered a sharp rise in pressure on these areas. This has led to the clearing of forest remnants and the replacement of cabruca areas for crops that interrupted the landscape connectivity, such as coffee and pasture. The region also became a major focus of illegal trade in native wood of the Central Atlantic Forest Corridor leading to serious erosion of biodiversity of forest areas that have not been cleared. In addition to habitat loss, high levels of hunting and illegal extraction of palm heart result in loss of biodiversity (Fonseca et al., 2004).

The remaining forests of southern Bahia, although small, fragmented and inserted into a mosaic of secondary vegetation, harbor some of the highest levels of biodiversity and endemism on the planet (Silva \& Casteleti, 2005). It is also unique in sharing lowland Amazonia-related taxa such as the Cinereous Antshrike Thamnomanes caesius and the Screaming Piha Lipaugus vociferans (Aguiar et al., 2005). Although vegetation of this region is still poorly known from a floristic viewpoint, recent studies demonstrate extraordinary biological richness and species endemism (Thomas et al., 1998; Thomas, 2003). For this reason, it is one of the areas of highest priority within the Central Corridor of the Atlantic Forest. To reinforce its biological importance and high rates of endemism, the scientific crew created by the Ministry of the Environment to identify and propose areas for the creation of new protected areas recommended the creation of the Wildlife Refuge Serra do Baixão-Serra Bonita with an area of 33,000 hectares (Timmers, 2006).

According to the Instituto de Estudos Socioambientais do Sul da Bahia, Una-Serra do Baixão, which encompass the Serra Bonita complex, has a total area of 330,295 hectares. There are only two federal protected areas within this forest continuum: Una Biological Reserve (recently expanded to $18,500 \mathrm{ha}$ ) and the Una Wildlife Refuge (23,400 ha). However, in its current form, the public system of protected areas is not enough to reverse this situation nor to ensure the conservation and sustainable use of biodiversity in the long term. The main factors are two-fold: (1) the absolute area of the integral protected region is inadequate and (2) the distribution of protected areas through geographic and biological viewpoints is irregular and are concentrated in the region of Una (Descobrimento, Monte Pascoal and PauBrasil national parks). Thus, there are significant gaps in the remaining mountains, particularly in sub montane rainforests. Current protected areas suffer severe staff and financial resources limitations to ensure their effective management and supervision and despite its expan- sion into $7,100 \mathrm{ha}$, the land tenure of more than $50 \%$ of the Una Biological Reserve is not regularized (Diniz da Cruz, pers. com.).

Considering that southern Bahia suffered a severe forest clearing in the state between 2015 and 2016 (SOS Mata Atlântica \& INPE, 2017), protected areas are of paramount importance to biodiversity. Within this context, Private Natural Heritage Reserves (PNHR) become crucial to strengthen the public protected areas system by filling gaps, increasing absolute areas under protection, conserving unique unprotected habitats and increasing connectivity in the landscape (Pinto et al., 2004). Within the Serra do Baixão, Serra Bonita PNHR is a key core area that has a significant role in increasing the absolute area of the region under full protection including a significant portion of sub montane and montane forests, a unique habitat still not represented by public protected areas. Serra Bonita is also exceptionally important for bird conservation, considered an Important Bird Area (BA 23, BR 111), with globally threatened and range-restricted species (Bencke et al., 2006; IUCN, 2016). This is the third largest number of endangered and endemic species out of the 31 Important Bird Areas (IBA) in Bahia (Bencke et al., 2006). Serra Bonita represents $>50 \%$ of the total area of the protected PNHR in southern Bahia and the incorporation of 725 ha of land already acquired by third parties as well as the acquisition of 1,045 ha through the Instituto Uiraçu will eventually expand it area to 2,700 ha (V. Becker, pers. com.).

Hellmayr's (1929) and Pinto's (1935) are still the main authorities regarding the Bahian ornithological state of the art. Few recent studies have gathered significant information on birds from this state, including southern Bahia (Gonzaga et al., 1995; Silveira et al., 2005). The absence of a state-level threatened species list is a consequence of the lack of studies within this region. Despite its biological representativeness, there are still significant gaps in knowledge of faunal groups, particularly regarding terrestrial vertebrates. Since the knowledge of composition of groups of vertebrates in any given area is a prime factor to define measures for their conservation (Heyer et al., 1994), the implementation of targeted and applied studies on amphibians, mammals and birds of the Serra Bonita and its surroundings proves decisive for the success of the area to conserve biodiversity in the long term. We surveyed the birds of Serra Bonita to provide basic elements for defining and monitoring measures to significantly enhance the ornithological knowledge of this PNHR.

\section{MATERIAL AND METHODS}

Serra Bonita PNHR is located south of Una-Serra do Baixão, in the municipalities of Camacan and Pau Brasil, southeastern Bahia, northeastern Brazil (Fig. 1). A significant part of this IBA, which has ca. 7,500 ha, is included in PNHR Serra Bonita I, II, III and IV, forming a 2,700 ha forest block. Well-preserved forests cover the elevational gradient (from 200 to $950 \mathrm{~m}$ ) of the mountains with rainforests richly covered in epiphytes. Above $600 \mathrm{~m}$, there 


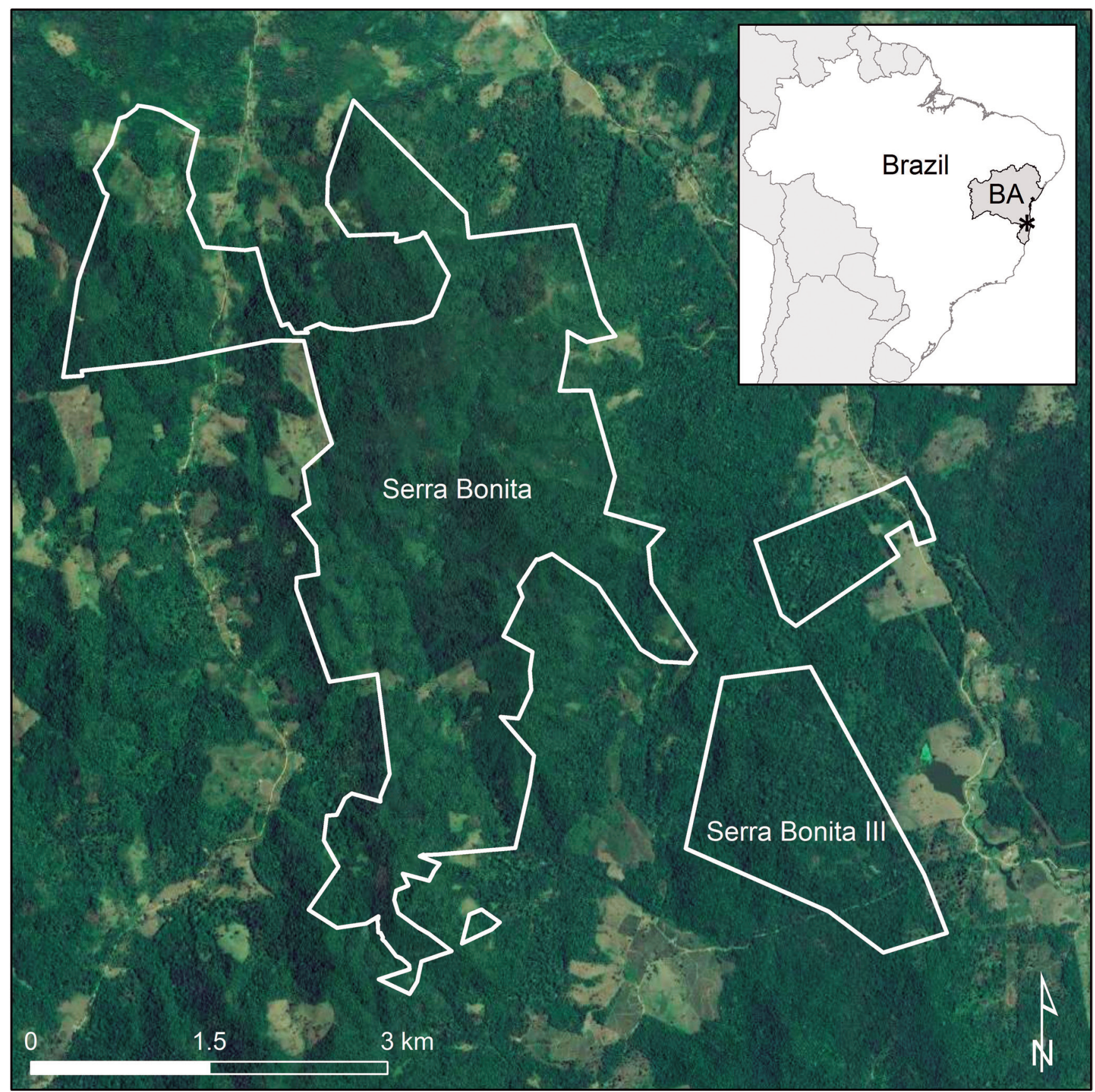

Figure 1. Location of Serra Bonita NHPR in northeast Brazil.

is frequent formation of dense fog, which renders montane forests a wetter aspect than the adjacent lowlands (BirdLife International, 2016). The latter include semideciduous forests whereas montane rainforests are typically found on higher elevations. This whole area is part of a mountain range that stands out in the landscape of south-eastern Bahia, contiguous to Serra das Lontras (currently a National Park), Serra do Javi and Serra do Teimoso (BA 20 and BA 22, BirdLife International, 2016).

Since 1980, authors have unsystematically surveyed birds at several farms that compose the Serra Bonita PNHR. We performed more concentrated efforts between 12-22 December 2010, when we visited two trails

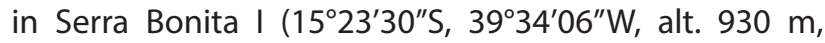
and $15^{\circ} 23^{\prime} 44^{\prime \prime} \mathrm{S}, 39^{\circ} 24^{\prime} 25^{\prime \prime} \mathrm{W}$, alt. $890 \mathrm{~m}$ ) and two sites in
Serra Bonita III (15² $25^{\prime} 29^{\prime \prime}$ S, 39 $32^{\prime} 31^{\prime \prime} \mathrm{W}$, alt. $174 \mathrm{~m}$, and $15^{\circ} 25^{\prime} 06^{\prime \prime} \mathrm{S}, 39^{\circ} 32^{\prime} 38^{\prime \prime} \mathrm{W}$, alt. $\left.208 \mathrm{~m}\right)$. Lower elevations include Fazenda Paris and Santo Antônio (15²5'07"S, $39^{\circ} 32^{\prime} 44^{\prime \prime} \mathrm{W}$, alt. $268 \mathrm{~m}$ ), part of the reserve. For five months (June-October 2017), one of us (CA) also walked all trails of all farms on a weekly basis. In those areas, we walked randomly at a constant speed of about $1.5 \mathrm{~km} / \mathrm{h}$ on several environments to record the largest number of species possible. We visually identified birds with the aid of binoculars and recorded vocalizations with a TASCAM DR-40 and shotgun microphones. These are deposited at Seção de Aves do Museu de Zoologia da Universidade de São Paulo (MZUSP), where we also deposited some collected specimens. We included non-systematic crepuscular observations to register nocturnal species. 
We began transect counts $c a$. 15 minutes before sunrise and lingered, at the minimum, for 2 hours when weather conditions permitted, i.e., when there was no rain or intense winds. It allowed us to ensure that the detectability of the birds would not be significantly affected. We conducted surveys along trails, secondary growth and forest edges. The total number of census resulted in over 100 days. In addition, in 2010 we used 20-30 mist nets ( $12 \mathrm{~m} \times 3 \mathrm{~m}$, mesh $36 \mathrm{~mm}$ ) along the same trails used for surveys. We opened mist nets, mounted at ground level, at $06 \mathrm{~h} 00$ and closed them around $17 \mathrm{~h} 00$ or earlier in accordance with climatic conditions. Standardization of capture effort is in accordance with the following equation: $E=$ area.h.n (1), where $E$ is capture effort, area corresponds to the area of each net (height multiplied by width), $h$ is exposure time (number of hours multiplied by the number of days) and $n$ is the number of nets. We expressed results in h.m ${ }^{2}$ (Roos, 2010) and accumulated 19,584 h.m ${ }^{2}$ of net effort. We followed Straube's et al. (2010) suggestions for the standardization of environmental impact studies surveys, which also apply for our own objectives. Hence, database (rather than secondary data) are records from literature and museums (and in this case, previous visits by CA, LFS, JFP and BMW to Serra Bonita). In addition, we searched and critically revised Wikiaves (http://wikiaves.com.br) database from Serra Bonita private reserve and Camacan and Pau Brasil municipalities as of 12 December 2018 which resulted in some additions to the species list. We obtained field data, synonymous with primary data, in situ.

We used a Jaccard similarity index to compare species richness similarity between highlands and lowlands based on species present on both environments, as follows: ${ }^{\prime \prime}=\frac{c}{a+b+c}(2)$, where $J^{\prime}$ is the actual index, $a$ equals the number of exclusive species on a given site, $b$ equals the number of exclusive species on a different given site and $c$ equals the number of shared species between sites (Krebs, 1999). Taxonomic arrangements follow the most recent list of the Comitê Brasileiro de Registros Ornitológicos (Piacentini et al., 2015).

\section{RESULTS}

We recorded a total of 368 species, 276 at Serra Bonita (I and III) and 244 at Fazenda Paris (as well as another 56 only on surroundings). This corresponds to $45 \%$ of all bird species of the state of Bahia (Souza \& Borges, 2008). As of 12 December 2018, the Wikiaves site reported one species from Pau Brasil and 258 species from Camacan, including three species we had not recorded in situ: Pseudoseisura cristata, Progne chalybea and Tangara brasiliensis. Combined with colleagues' records, Serra Bonita is the stronghold for 371 species of birds. Of this total, 13 species are under threat categories in Brazil (ICMBio, 2016), and as many as 16 species are either globally vulnerable or endangered (Appendix; IUCN, 2016).

Some 67 (18\%) species recorded at Serra Bonita PNHR are Atlantic Forest endemic species according to Bencke et al. (2006; Appendix). If one includes subspecies, then another 143 are Atlantic forest endemic taxa, in which case Serra Bonita harbors 108 taxa exclusive to this domain. Of these, the Olivaceous Woodcreeper Sittasomus griseicapillus olivaceus, inhabits southern Bahia only, and another six subspecies are threatened in Brazil. Because IUCN does not yet denote global extinction risk at the subspecies level, we call attention for a major gap in the knowledge of such taxa, which should be the objective of future taxonomic revisions.

We detected 93 (25\%) species exclusively in the highlands (above $500 \mathrm{~m}$ ), while 61 (22\%) were only recorded in lowlands. The similarity index between the bird community in distinct elevational ranges was $\mathrm{J}^{\prime}=0.54$, with 183 shared species.

\section{DISCUSSION}

Serra Bonita PNHR is the single locality with the highest species richness in all available inventories in Bahia. Not only the absolute number of species is remarkable, but also the percentage of endemic and threatened species has no parallel in the state (see Pinto, 1993; Gonzaga et al., 1995; Parrini et al., 1999; Silveira et al., 2005; Laps, 2006; Vasconcelos et al., 2012; Morante-Filho et al., 2015, 2016, 2018). From southern Bahia south to northern Rio de Janeiro, the lowlands harbor Amazonia-related taxa, whereas, in the highlands, Atlantic Forest-related elements are typically found (e.g., Willis \& Oniki 2002; Silveira et al., 2005; Mallet-Rodrigues et al., 2010). Serra Bonita is no exception. Lowland Amazonian taxa include Thamnomanes caesius and Lipaugus vociferans. Like Serra das Lontras (Silveira et al., 2005), the entire elevational gradient, which in Serra Bonita is largely preserved, is necessary to maintain this biodiversity.

Due to the continuity and preservation of these forests, Serra Bonita PNHR may be a promising location to find some rare and threatened Atlantic Forest endemic taxa not yet recorded. In Bahia such species can be found almost exclusively at Una Biological Reserve or Pau-Brasil/Trancoso, Monte Pascoal and Descobrimento National Parks, situated within a 100 km radius (e.g., Laps, 2006), such as the Red-billed Curassow Crax blumenbachii. At Serra Bonita NHPR recent records of the Harpy Eagle Harpia harpyja, with breeding pairs and still relatively common in Amazonia but now very rare in the Atlantic forest (Galetti et al., 1997) also indicate the pristine conditions of local forests. There are a few recent records from southern Bahia as well, such as Serra das Lontras (Silveira et al., 2005), Estação Experimental PauBrasil, municipality of Porto Seguro, and a photograph of a young Harpy Eagle at Serra Bonita I (Sánchez-Lalinde et al., 2011). At Serra Bonita, V. Becker sighted a couple on forest border August 2015, and saw one individual close to the research facility August 2016. LFS also heard one individual calling at Fazenda Santa Antônio in May 2016 and an active nest was discovered in February 2018 (V. Becker, pers. comm.). We found as fairly common in the highlands a treehunter Heliobletus sp. which is being scientifically described (Whitney et al. in prep.). The taxon 
also occurs at Serra das Lontras (Silveira et al., 2005) and is only found at higher elevations. This isolated population is currently under description and will be endemic to these southern Bahian mountains.

For harboring the greatest species richness, Atlantic Forest endemic species and globally threatened birds in Bahia, and because even more endemic and threatened species are likely to be found with increasing surveys, we urge that unprotected areas surrounding Serra Bonita be immediately incorporated into a permanent protection conservation unit. This act will enhance the survival of this entire ecosystem, already almost completely extirpated and fragmented, found nowhere else on Earth. In addition, cabrucas support high species richness of birds but do not act as surrogates for intact forests. The presence and representativeness of some forest species seem to depend on the existence of nearby native forests (Faria et al., 2006, 2007; Pardini et al., 2009). Pacheco et al. (1996) recognized the dire interface of cocoa growers in southern Bahia being forced to abandon their livelihoods in favor of cutting old cabruca canopies and planting other crops (such as bananas and coffee) with preservation of forests. To the point, they called for the immediate preservation of two blocks of land covering the elevational range from the lowlands to the tops of the highest peaks, one in the Serra das Lontras and the other in the Serra Bonita. As integral parts of the conservation plan, they recommended inclusion of extensive blocks of cabruca canopies; removal of the introduced cocoa trees; and planting of native seedling trees while ancient native "shade" trees were still present and dropping seeds annually. They further recommended that local people, especially large land owners, be integrally involved in the creation and maintenance of these forest reserves. Now, some 20 years later, good progress has been made in both the Serra das Lontras and Serra Bonita, and we still have the chance to follow through with these important directives.

\section{ACKNOWLEDGMENTS}

Our special thanks to Vitor and Clemira Beker (Instituto Uiraçu) for their vital work in preserving one of the most important fragments of Atlantic Forest in Bahia state. The Fundação O Boticario de Proteção à Natureza funded part of this research. VC received field equipment from IdeaWild. We also thank the Instituto Chico Mendes de Conservação da Biodiversidade (ICMBio) for collecting permits and Conselho Nacional de Desenvolvimento Científico e Tecnológico (CNPq) for the grants and financial support to LFS.

\section{REFERENCES}

Aguiar, A.P.; Chiarello, A.G.; Mendes, S.L. \& Matos, E.N. 2005. Os Corredores Central e da Serra do Mar na Mata Atlântica brasileira. In: GalindoLeal, C. \& Câmara, I.G. (Eds.). Mata Atlântica. Biodiversidade, ameaças e perspectivas. São Paulo, Fundação SOS Mata Atlântica; Belo Horizonte, Conservação Internacional. p. 119-132.
Alger, K. \& Caldas, M. 1996. Cacau na Bahia: decadência e ameaça à Mata Atlântica. Ciência Hoje, 20: 28-35.

Araújo, M.; Alger, K.; Rocha, R. \& Mesquita, C.A.B. 1998. A Mata Atlântica do sul da Bahia: situação atual, ações e perspectivas. São Paulo, Conselho Nacional da Reserva da Biosfera da Mata Atlântica - MAB - UNESCO. 36p. (Cadernos da Reserva da Biosfera, n. 8).

Bencke, G.A.; Mauricio, G.N.; Develey, P.F. \& Goerck, J.M. 2006. Áreas importantes para a conservação de Aves no Brasil, Parte I - Estados do Domínio da Mata Atlântica. São Paulo, SAVE Brasil.

BirdLife International. 2016. Important Bird Areas factsheet: Serra Bonita. Available at: http://www.birdlife.org. Access in: 30/10/2016.

Câmara, I.G. 2005. Breve história da conservação da Mata Atlântica. In: Galindo-Leal, C. \& Câmara, I.G. (Eds.). Mata Atlântica. Biodiversidade, ameaças e perspectivas. Belo Horizonte, Fundação SOS Mata Atlântica; São Paulo, Conservação Internacional. p. 31-42.

Faria, D.; Laps, R.R.; Baumgarten, J. \& Cetra, M. 2006. Bat and bird assemblages from forests and shade cacao plantations in two contrasting landscapes in the Atlantic Forest of southern Bahia, Brazil. Biodiversity \& Conservation, 15: 587-612.

Faria, D.; Paciência, M.L.B; Dixo, M.; Laps, R.R. \& Baumgarten, J. 2007. Ferns, frogs, lizards, birds and bats in forest fragments and shade cocoa plantations in two contrasting landscapes in the Atlantic forest, Brazil. Biodiversity Conservation, 16: 2335-2357.

Fonseca, G.A.B.; Alger, K.; Pinto, L.P.; Araújo, M. \& Cavalcanti, R. 2004. Corredores de Biodiversidade: 0 Corredor Central da Mata Atlântica. In: Arruda, M.B. \& Sá, L.F.S.N. (Orgs.). Corredores Ecológicos: uma abordagem integradora de ecossistemas no Brasil. Brasília, IBAMA. p. 47-65.

Galetti, M.; Martuscelli, P.; Pizo, M.A. \& Simão, I. 1997. Records of harpy and crested eagles in the Brazilian Atlantic Forest. Bulletin of the British Ornithologists' Club, 117: 27-31.

Goerck, J.M. 1997. Patterns of rarity in the birds of the Atlantic Forest of Brazil. Conservation Biology, 11: 112-118.

Gonzaga, L.A.P.; Pacheco, J.F.; Bauer, C. \& Castiglioni, G.D.A. 1995. An avifaunal survey of the vanishing montane Atlantic forest of southern Bahia, Brazil. Bird Conservation International, 5: 279-290.

Hellmayr, C.E. 1929. A contribution to the ornithology of northeastern Brazil. Field Museum of Natural History. Zoology, 7: 235-501.

Heyer, W.R.; Donnelly, M.A.; McDiarmid, R.W.; Hayek, L.C. \& Foster, M.S. 1994. Measuring and monitoring biological diversity. Standard methods for amphibians. Washington, Smithsonian Institution Press.

ICMBio - Instituto Chico Mendes de Conservação da Biodiversidade. 2016. Sumário Executivo do Livro Vermelho da Fauna Brasileira Ameaçada de Extinção. Brasília, ICMBio.

IUCN - International Union for Conservation of Nature and Natural Resources. The IUCN Red List of Threatened Species. Available at: http://www. iucnredlist.org. Access in: 03/03/2018.

Krebs, C.J. 1999. Ecological Methodology. Los Angeles, Benjamins Cammings.

Laps, R.R. 2006. Efeito da fragmentação e alteração do hábitat na avifauna da região da Reserva Biológica de Una, Bahia. (Masters Dissertation). Campinas, Universidade Estadual de Campinas.

Mallet-Rodrigues, F.; Parrini, R.; Pimentel, L.M.S. \& Bessa, R. 2010. Altitudinal distribution of birds in a mountainous region in southeastern Brazil. Zoologia, 27: 503-522.

May, P.H. \& Rocha, R.B. 1996. 0 sistema agrossilvicultural do cacau-cabruca. In: Lopes, I.V.; Bastos Filho, G.S.; Biller, D. \& Bale, M. (Eds.). Gestão Ambiental no Brasil: Experiência e Sucesso. São Paulo, Fundação Getúlio Vargas Editora. p. 35-61.

Morante-Filho, J.C.; Arroyo-Rodríguez, V. \& Faria, D. 2016. Patterns and predictors of $\beta$-diversity in the fragmented Brazilian Atlantic forest: a 
multiscale analysis of forest specialist and generalist birds. Journal of Animal Ecology, 85: 240-250.

Morante-Filho, J.C.; Arroyo-Rodríguez, V.; de Andrade, E.R.; Santos, B.A.; Cazetta, E. \& Faria, D. 2018. Compensatory dynamics maintain bird phylogenetic diversity in fragmented tropical landscapes. Journal of Applied Ecology, 55: 256-266.

Morante-Filho, J.C.; Faria, D.; Mariano-Neto, E. \& Rhodes, J. 2015. Birds in anthropogenic landscapes: the responses of ecological groups to forest loss in the Brazilian Atlantic Forest. PLoS One, 10: e0128923.

Myers, N.; Mittermeier, R.A.; Mittermeier, C.G.; Fonseca, G.A.B. \& Kent, J. 2000. Biodiversity hotspots for conservation priorities. Nature, 403: 853-858.

Cerqueira Neto, S.P.G. 2012. Três décadas de eucalipto no extremo sul da Bahia. GEOUSP - Espaço e Tempo, 31: 55-68.

Pacheco, J.F.; Whitney, B.M. \& Gonzaga, L.P. 1996. A new genus and species of furnariid (Aves: Furnariidae) from the cocoa-growing region of southeastern Bahia, Brazil. The Wilson Bulletin, 108: 397-433.

Pardini, R.; Faria, D.; Accacio, G.M.; Laps, R.R.; Mariano-Neto, E.; Paciencia, M.L.B.; Dixo, M. \& Baumgarten, J. 2009. The challenge of maintaining Atlantic forest biodiversity: a multi-taxa conservation assessment of specialist and generalist species in an agro-forestry mosaic in southern Bahia. Biological Conservation, 142: 1178-1190.

Parrini, R.; Raposo, M.A.; Pacheco, J.F.; Carvalhaes, A.M.P.; Melo-Júnior, T.A.; Fonseca, P.S.M. \& Minns, J.C. 1999. Birds of the Chapada Diamantina, Bahia, Brazil. Cotinga, 11: 86-95.

Piacentini, V.Q.; Aleixo, A.; Agne, C.E.; Maurício, G.N.; Pacheco, J.F.; Bravo, G.A.; Brito, G.R.R.; Naka, L.N.; Olmos, F.; Posso, S.; Silveira, L.F.; Betini, G.S.; Carrano, E.; Franz, I.; Lees, A.C.; Lima, L.M.; Pioli, D.; Schunck, F.; Amaral, F.R.; Bencke, G.A.; Cohn-Haft, M.; Figueiredo, L.F.A.; Straube, F.C. \& Cesari, E. 2015. Annotated checklist of the birds of Brazil by the Brazilian Ornithological Records Committee / Lista comentada das aves do Brasil pelo Comitê Brasileiro de Registros Ornitológicos. Revista Brasileira de Ornitologia, 23: 91-298.

Pinto, L.P.; Paglia, A.; Paese, A. \& Fonseca, M. 2004.0 papel das reservas privadas na conservação da biodiversidade. In: Castro, R. \& Borges, M.E. (Orgs.). RPPN: Conservação em Terras Privadas - desafios para a sustentabilidade. Planaltina do Paraná, Edições CNRPPN. p. 14-27.

Pinto, L.P.S. 1993. Inventário avifaunístico e conservação da Mata Atlântica do Sul da Bahia, Brasil. Belo Horizonte, Fundação Biodiversitas.

Pinto, 0.M.0. 1935. Aves da Bahia. Revista do Museu Paulista, 19: 1-325.

Ribeiro, M.C.; Metzger, J.P.; Martensen, A.C.; Ponzoni, F.J. \& Hirota, M.M. 2009. The Brazilian Atlantic Forest: How much is left, and how is the remaining forest distributed? Implications for conservation. Biological Conservation, 142: 1141-1153.

Roos, A.L. 2010. Capturando aves. In: Matter, S.; Straube, F.C.; Accordi, I.; Piacentini, V. \& Cândido-Jr., J.F. (Orgs.). Ornitologia e Conservação. Ciência aplicada, técnicas de pesquisa e levantamento. Rio de Janeiro, Technical Books. p. 77-104.
Sánchez-Lalinde, C.; Vélez-García, F.; Cornélio, A.C.; Silveira, L.F. \& Alvarez, M.R. 2011. Records of the Harpy Eagle (Harpia harpyja) in the Serra Bonita reserves complex, Camacan, Bahia, with evidence of breeding. Revista Brasileira de Ornitologia, 19: 436-438.

Silva, J.M.C. \& Casteleti, C.H.M. 2005. Estado da biodiversidade da Mata Atlântica brasileira. In: Galindo-Leal, C. \& Câmara, I.G. (Eds.). Mata Atlântica. Biodiversidade, ameaças e perspectivas. São Paulo, Fundação SOS Mata Atlântica; Belo Horizonte, Conservação Internacional. p. 43-59.

Silva, W.G.S.; Metzger, J.P.; Simões, S. \& Simonetti, C. 2007. Relief influence on the spatial distribution of the Atlantic Forest cover at the Ibiúna Plateau, SP. Brazilian Journal of Biology, 67: 403-411.

Silveira, L.F.; Develey, P.F.; Pacheco, J.F. \& Whitney, B.M. 2005. Avifauna of the Serra das Lontras-Javi montane complex, Bahia, Brazil. Cotinga, 24: 45-54.

SOS Mata Atlântica \& INPE - Instituto Nacional de Pesquisas Espaciais. 2017. Atlas dos Remanescentes Florestais da Mata Atlântica. Período 2016-2016. São Paulo, SOS Mata Atlântica \& São José dos Campos, INPE.

Souza, D.G.S. \& Borges, 0.B. 2008. Lista das aves do Estado da Bahia. Available at: http://www.ce0.org.br/listas de aves/BA\%20-\%20Deodato\%20 Souza\%20-\%202008.pdf. Access in: 10/02/2018.

Straube, F.C.; Vasconcelos, M.F.; Urben-Filho, A. \& Cândido-Jr., J.F. 2010. Protocolo mínimo para levantamentos de avifauna em Estudos de Impacto Ambiental. In: Matter, S.; Straube, F.C.; Accordi, I.; Piacentini, V. \& Cândido-Jr., J.F. (Orgs.). Ornitologia e Conservação. Ciência aplicada, técnicas de pesquisa e levantamento. Rio de Janeiro, Technical Books. p. 237-254.

Thomas, W.M.; Carvalho, A.M.V.; Amorim, A.M.A.; Garrison, J.; Arbeláez, A.L. 1998. Plant endemism in two forests in Southern Bahia, Brazil. Biodiversity \& Conservation, 7: 311-322.

Thomas, W.W. 2003. Natural vegetation types in southern Bahia. In: Prado, P.I.; Landau, E.C.; Moura, R.T.; Pinto, L.P.S.; Fonseca, G.A.B \& Alger, K. (Orgs.). Corredor da biodiversidade da Mata Atlântica do sul da Bahia. Ilhéus, IESB/IESB/CI/CABS/UFMG/UNICAMP. [Publicação em CD ROM].

Timmers, J.F. 2006. Equipe Técnico-científica para ampliação da Rede de Unidades de Conservação de Proteção Integral no Baixo Sul, Sul e Extremo Sul da Bahia. Propostas Consolidadas de Ampliação e Criação de Unidades de Conservação no Baixo Sul, Sul e Extremo Sul da Bahia. Projeto (FAO) GCP/BRA/061/WBK Contrato № 2005/384. [Relatório não publicado]

Vasconcelos, M.F.; Souza, L.N.; Duca, C.; Pacheco, J.F.; Parrini, R.; Serpa, G.A.; Albano, C.; Abreu, C.R.M.; Santos, S.S. \& Fonseca-Neto, F.P. 2012. The avifauna of Brejinho das Ametistas, Bahia, Brazil: birds in a caatinga-cerrado transitional zone, with comments on taxonomy and biogeography. Revista Brasileira de Ornitologia, 20: 246-267.

Willis, E.O. \& Oniki, Y. 2002. Birds of Santa Teresa, Espírito Santo, Brazil: do humans add or subtract species? Papéis Avulsos Zoologia, 42: 193-264. 


\section{APPENDIX}

List of bird taxa recorded within Serra Bonita. Subspecific nomenclature are tentatively placed according to location and follow Piacentini et al. (2015) and MZUSP data when specimens are available. An asterisk indicates a taxa endemic of Atlantic Forest $(n=143)$. Paris and Santo Antônio Farms $(<500 \mathrm{~m})$ and Serra Bonita I and III $(>500 \mathrm{~m})$; S stands for surroundings. Acronyms refer to authors who recorded some species during initial observations. WA indicates records deposited online. The last two columns refer to endangered taxa globally (IUCN) and in Brazil (ICMBio).

\begin{tabular}{|c|c|c|c|c|c|c|c|}
\hline Taxa & English name & $<500 \mathrm{~m}$ & $>500 \mathrm{~m}$ & $s$ & WA & IUCN & ICMBio \\
\hline \multicolumn{8}{|l|}{ Tinamiformes } \\
\hline \multicolumn{8}{|l|}{ Tinamidae } \\
\hline Tinamus solitarius* & Solitary Tinamou & & $x$ & & & & \\
\hline Crypturellus soui albigularis & Little Tinamou & $x$ & jfp & & $x$ & & \\
\hline Crypturellus o. obsoletus* & Brown Tinamou & Ifs & $x$ & & $x$ & & \\
\hline Crypturellus tataupa lepidotus & Tataupa Tinamou & $x$ & & & & & \\
\hline Rhynchotus r. rufescens & Red-winged Tinamou & & & $x$ & & & \\
\hline \multicolumn{8}{|l|}{ Anseriformes } \\
\hline \multicolumn{8}{|l|}{ Anatidae } \\
\hline Cairina moschata & Muscovy Duck & & & $x$ & & & \\
\hline Amazonetta b. brasiliensis & Brazilian Teal & & & $x$ & $x$ & & \\
\hline \multicolumn{8}{|l|}{ Galliformes } \\
\hline \multicolumn{8}{|l|}{ Cracidae } \\
\hline Penelope superciliaris jacupemba & Rusty-margined Guan & & $x$ & & $x$ & & \\
\hline Ortalis araucuan* & East Brazilian Chachalaca & $x$ & $x$ & & & & \\
\hline \multicolumn{8}{|l|}{ Odontophoridae } \\
\hline Odontophorus c. capueira* & Spot-winged Wood-Quail & & $x$ & & & & \\
\hline \multicolumn{8}{|l|}{ Podicipediformes } \\
\hline \multicolumn{8}{|l|}{ Podicipedidae } \\
\hline Tachybaptus dominicus brachyrhynchus & Least Grebe & & & $x$ & & & \\
\hline Podilymbus podiceps antarcticus & Pied-billed Grebe & & & $x$ & & & \\
\hline \multicolumn{8}{|l|}{ Suliformes } \\
\hline \multicolumn{8}{|l|}{ Phalacrocoracidae } \\
\hline Nannopterum b. brasilianus & Neotropic Cormorant & & & $x$ & & & \\
\hline \multicolumn{8}{|l|}{ Pelecaniformes } \\
\hline \multicolumn{8}{|l|}{ Ardeidae } \\
\hline Tigrisoma lineatum marmoratum & Rufescent Tiger-Heron & & & $x$ & $x$ & & \\
\hline Nycticorax nycticorax hoactli & Black-crowned Night-Heron & & & $x$ & & & \\
\hline Butorides s. striata & Striated Heron & & & $x$ & & & \\
\hline Bubulcusi.ibis & Cattle Egret & & & $x$ & & & \\
\hline Ardea cocoi & Cocoi Heron & & & $x$ & & & \\
\hline Ardea alba egretta & Great Egret & & & $x$ & & & \\
\hline Pilherodius pileatus & Capped Heron & & & $x$ & $x$ & & \\
\hline Egretta t. thula & Snowy Egret & & & $x$ & & & \\
\hline \multicolumn{8}{|l|}{ Cathartiformes } \\
\hline \multicolumn{8}{|l|}{ Cathartidae } \\
\hline Cathartes aura ruficollis & Turkey Vulture & $x$ & $x$ & & $x$ & & \\
\hline Cathartes burrovianus urubutinga & Lesser Yellow-headed Vulture & $x$ & $x$ & & $x$ & & \\
\hline Coragyps atratus brasiliensis & Black Vulture & $x$ & $x$ & & $x$ & & \\
\hline Sarcoramphus papa & King Vulture & $x$ & $x$ & & $x$ & & \\
\hline \multicolumn{8}{|l|}{ Accipitriformes } \\
\hline \multicolumn{8}{|l|}{ Accipitridae } \\
\hline Leptodon cayanensis & Gray-headed Kite & $x$ & & & & & \\
\hline Elanoides forficatus ssp. & Swallow-tailed Kite & $x$ & jfp & & & & \\
\hline Harpagus diodon & Rufous-thighed Kite & $x$ & & & $x$ & & \\
\hline Ictinia plumbea & Plumbeous Kite & $x$ & & & $x$ & & \\
\hline Geranospiza caerulescens gracilis & Crane Hawk & $x$ & & & $x$ & & \\
\hline Heterospizias meridionalis & Savanna Hawk & & & $x$ & & & \\
\hline Urubitinga u. urubitinga & Great Black Hawk & $x$ & & & & & \\
\hline Rupornis magnirostris nattereri & Roadside Hawk & $x$ & Ifs & & $x$ & & \\
\hline Geranoaetus a. albicaudatus & White-tailed Hawk & $x$ & Ifs & & $x$ & & \\
\hline
\end{tabular}




\begin{tabular}{|c|c|c|c|c|c|c|c|}
\hline Taxa & English name & $<500 \mathrm{~m}$ & $>500 \mathrm{~m}$ & $S$ & WA & IUCN & ICMBio \\
\hline Pseudastur polionotus & Mantled Hawk & $x$ & $x$ & & $x$ & & \\
\hline Buteo nitidus pallidus & Gray-lined Hawk & $x$ & & & & & \\
\hline Buteo albonotatus & Zone-tailed Hawk & $x$ & $x$ & & $x$ & & \\
\hline Harpia harpyja & Harpy Eagle & $x$ & & & & & VU \\
\hline Spizaetus t. tyrannus & Black Hawk-Eagle & $x$ & $x$ & & $x$ & & \\
\hline Spizaetus melanoleucus & Black-and-white Hawk-Eagle & & $x$ & & $x$ & & \\
\hline Spizaetus 0. ornatus & Ornate Hawk-Eagle & & & jfp & & & \\
\hline \multicolumn{8}{|l|}{ Gruiformes } \\
\hline \multicolumn{8}{|l|}{ Rallidae } \\
\hline Aramides cajaneus & Gray-necked Wood-Rail & $x$ & & & & & \\
\hline Aramides saracura* & Slaty-breasted Wood-Rail & & jfp & & & & \\
\hline Amaurolimnas concolor castaneus & Uniform Crake & $x$ & & & $x$ & & \\
\hline Laterallus m. melanophaius & Rufous-sided Crake & & & $x$ & & & \\
\hline Mustelirallus a. albicollis & Ash-throated Crake & & & $x$ & $x$ & & \\
\hline Pardirallus n. nigricans & Blackish Rail & & $x$ & & & & \\
\hline Gallinula g. galeata & Common Gallinule & & Ifs & $x$ & & & \\
\hline Porphyrio martinicus & Purple Gallinule & & & $x$ & $x$ & & \\
\hline \multicolumn{8}{|l|}{ Charadriiformes } \\
\hline \multicolumn{8}{|l|}{ Charadriidae } \\
\hline Vanellus chilensis lampronotus & Southern Lapwing & Ifs & & $x$ & & & \\
\hline \multicolumn{8}{|l|}{ Scolopacidae } \\
\hline Gallinago p. paraguaiae & South American Snipe & & & $x$ & & & \\
\hline Gallinago undulata gigantea & Giant Snipe & & & $x$ & & & \\
\hline \multicolumn{8}{|l|}{ Jacanidae } \\
\hline Jacanaj.jacana & Wattled Jacana & Ifs & Ifs & $x$ & & & \\
\hline \multicolumn{8}{|l|}{ Columbiformes } \\
\hline \multicolumn{8}{|l|}{ Columbidae } \\
\hline Columbina t. talpacoti & Ruddy Ground-Dove & Ifs & Ifs & $x$ & & & \\
\hline Claravis pretiosa & Blue Ground-Dove & $x$ & $x$ & & & & \\
\hline Patagioenas speciosa & Scaled Pigeon & $x$ & jfp & & $x$ & & \\
\hline Patagioenas picazuro marginalis & Picazuro Pigeon & $x$ & & & & & \\
\hline Patagioenas p. plumbea* & Plumbeous Pigeon & $x$ & $x$ & & $x$ & & \\
\hline Leptotila verreauxi decipiens & White-tipped Dove & $x$ & $x$ & & & & \\
\hline Leptotila rufaxilla bahiae & Gray-fronted Dove & $x$ & $x$ & & $x$ & & \\
\hline Geotrygon m. montana & Ruddy Quail-Dove & $x$ & $x$ & & $x$ & & \\
\hline \multicolumn{8}{|l|}{ Cuculiformes } \\
\hline \multicolumn{8}{|l|}{ Cuculidae } \\
\hline Piaya cayana macroura & Squirrel Cuckoo & $x$ & $x$ & & $x$ & & \\
\hline Coccyzus euleri & Pearly-breasted Cuckoo & & $\mathrm{x}$ & & $x$ & & \\
\hline Crotophaga ani & Smooth-billed Ani & $x$ & Ifs & & & & \\
\hline Guira guira & Guira Cuckoo & $x$ & Ifs & & & & \\
\hline Taperan.naevia & Striped Cuckoo & $x$ & jfp & & $x$ & & \\
\hline \multicolumn{8}{|l|}{ Strigiformes } \\
\hline \multicolumn{8}{|l|}{ Tytonidae } \\
\hline Tyto furcata tuidara & American Barn Owl & $x$ & & & & & \\
\hline \multicolumn{8}{|l|}{ Strigidae } \\
\hline Megascops choliba decussatus & Tropical Screech-Owl & $\mathrm{x}$ & $x$ & & $x$ & & \\
\hline Megascops atricapilla* & Black-capped Screech-0wl & $x$ & $x$ & & $x$ & & \\
\hline Pulsatrix perspicillata pulsatrix* & Spectacled 0wl & $x$ & & & $x$ & & \\
\hline Strix virgata borelliana* & Mottled Owl & $x$ & $x$ & & $x$ & & \\
\hline Strix huhula albomarginata* & Black-banded 0wl & $x$ & & & & & \\
\hline Glaucidium minutissimum* & Least Pygmy-0wl & $x$ & $x$ & & $x$ & & \\
\hline Glaucidium b. brasilianum & Ferruginous Pygmy-0wl & $x$ & Ifs & & $x$ & & \\
\hline Athene cunicularia grallaria & Burrowing 0wl & & & $x$ & & & \\
\hline \multicolumn{8}{|l|}{ Nyctibiiformes } \\
\hline \multicolumn{8}{|l|}{ Nyctibiidae } \\
\hline Nyctibius g. grandis & Great Potoo & $x$ & & & $x$ & & \\
\hline Nyctibius a. aethereus* & Long-tailed Potoo & $x$ & & & & & \\
\hline Nyctibius g. griseus & Common Potoo & $x$ & & & $x$ & & \\
\hline
\end{tabular}




\begin{tabular}{|c|c|c|c|c|c|c|c|}
\hline Taxa & English name & $<500 \mathrm{~m}$ & $>500 \mathrm{~m}$ & $S$ & WA & IUCN & ICMBio \\
\hline \multicolumn{8}{|l|}{ Caprimulgiformes } \\
\hline \multicolumn{8}{|l|}{ Caprimulgidae } \\
\hline Nyctiphrynus 0. ocellatus & Ocellated Poorwill & & $x$ & & $x$ & & \\
\hline Lurocalis semitorquatus nattereri & Short-tailed Nighthawk & $x$ & $x$ & & $x$ & & \\
\hline Nyctidromus a. albicollis & Common Pauraque & $x$ & $x$ & & $x$ & & \\
\hline Hydropsalis t. torquata & Scissor-tailed Nightjar & & $x$ & & & & \\
\hline \multicolumn{8}{|l|}{ Apodiformes } \\
\hline \multicolumn{8}{|l|}{ Apodidae } \\
\hline Streptoprocne z. zonaris & White-collared Swift & $x$ & $x$ & & $x$ & & \\
\hline Chaetura c. cinereiventris* & Gray-rumped Swift & $x$ & $x$ & & $x$ & & \\
\hline Chaetura meridionalis & Sick's Swift & & & jfp & & & \\
\hline Panyptila c. cayennensis & Lesser Swallow-tailed Swift & $x$ & $x$ & & $x$ & & \\
\hline \multicolumn{8}{|l|}{ Trochilidae } \\
\hline Glaucis dohrnii* & Hook-billed Hermit & $x$ & $x$ & & $x$ & EN & EN \\
\hline Glaucish. hirsutus & Rufous-breasted Hermit & $x$ & $x$ & & $x$ & & \\
\hline Phaethornis squalidus* & Dusky-throated Hermit & & jfp & & & & \\
\hline Phaethornis ruber pygmaeus & Reddish Hermit & $x$ & $x$ & & $x$ & & \\
\hline Phaethornis e eurynome* & Scale-throated Hermit & Ifs & $x$ & & $x$ & & \\
\hline Eupetomena macroura simoni & Swallow-tailed Hummingbird & $x$ & $x$ & & $x$ & & \\
\hline Aphantochroa cirrochloris & Sombre Hummingbird & & $x$ & & $x$ & & \\
\hline Florisuga fusca & Black Jacobin & & $x$ & & $x$ & & \\
\hline Anthracothorax nigricollis & Black-throated Mango & $x$ & $x$ & & $x$ & & \\
\hline Lophornis magnificus & Frilled Coquette & & $x$ & & $x$ & & \\
\hline Discosura l. langsdorffi* & Black-bellied Thorntail & & $x$ & & $x$ & & \\
\hline Chlorestes n. notata & Blue-chinned Sapphire & $x$ & & & $x$ & & \\
\hline Chlorostilbon lucidus pucherani & Glittering-bellied Emerald & & jfp & $x$ & $x$ & & \\
\hline Thalurania glaucopis* & Violet-capped Woodnymph & $x$ & $x$ & & $x$ & & \\
\hline Hylocharis sapphirina & Rufous-throated Sapphire & $x$ & & & $x$ & & \\
\hline Hylocharis c. cyanus* & White-chinned Sapphire & $x$ & jfp & & & & \\
\hline Amazilia l. lactea & Sapphire-spangled Emerald & & $x$ & & & & \\
\hline Heliodoxa rubricauda* & Brazilian Ruby & & $x$ & & $x$ & & \\
\hline Heliothryx auritus auriculatus & Black-eared Fairy & $x$ & $x$ & & $x$ & & \\
\hline Calliphlox amethystina & Amethyst Woodstar & & $x$ & & $x$ & & \\
\hline \multicolumn{8}{|l|}{ Trogoniformes } \\
\hline \multicolumn{8}{|l|}{ Trogonidae } \\
\hline Trogon viridis melanopterus* & Green-backed Trogon & $x$ & $x$ & & $x$ & & \\
\hline Trogon s. surrucura & Surucua Trogon & & $x$ & & $x$ & & \\
\hline Trogon rufus chrysochloros* & Black-throated Trogon & & $x$ & & $x$ & & \\
\hline \multicolumn{8}{|l|}{ Coraciiformes } \\
\hline \multicolumn{8}{|l|}{ Alcedinidae } \\
\hline Megaceryle t. torquata & Ringed Kingfisher & & & $x$ & & & \\
\hline Chloroceryle amazona & Amazon Kingfisher & & & $x$ & & EN & \\
\hline Chloroceryle a. americana & Green Kingfisher & & & $x$ & & & \\
\hline \multicolumn{8}{|l|}{ Galbuliformes } \\
\hline \multicolumn{8}{|l|}{ Galbulidae } \\
\hline Galbula ruficauda rufoviridis & Rufous-tailed Jacamar & $x$ & jfp & & $x$ & & \\
\hline \multicolumn{8}{|l|}{ Bucconidae } \\
\hline Notharchus swainsoni* & Buff-bellied Puffbird & $x$ & $x$ & & $x$ & & \\
\hline Nystalus maculatus & Spot-backed Puffbird & $x$ & Ifs & & & & \\
\hline Malacoptila s. striata* & Crescent-chested Puffbird & & $x$ & & $x$ & & \\
\hline Monasa m. morphoeus & White-fronted Nunbird & $x$ & & & $x$ & & \\
\hline Chelidoptera tenebrosa brasiliensis* & Swallow-winged Puffbird & $x$ & jfp & & $x$ & & \\
\hline \multicolumn{8}{|l|}{ Piciformes } \\
\hline \multicolumn{8}{|l|}{ Ramphastidae } \\
\hline Ramphastos vitellinus ariel & Channel-billed Toucan & $x$ & $x$ & & $x$ & & \\
\hline Ramphastos dicolorus* & & & Ifs & & & & \\
\hline Selenidera maculirostris* & Spot-billed Toucanet & $x$ & $x$ & & $x$ & & \\
\hline Pteroglossus bailloni* & Saffron Toucanet & $x$ & jfp & & $x$ & & \\
\hline Pteroglossus a. aracari & Black-necked Aracari & $x$ & $x$ & & $x$ & & \\
\hline
\end{tabular}




Taxa English name

$<500 \mathrm{~m}$

$>500 \mathrm{~m}$

s

WA IUCN

ICMBio

\section{Picidae}

Picumnus exilis*

Bahia Piculet

Picumnus pygmaeus

Spotted Piculet

Picumnus albosquamatus guttifer

Melanerpes candidus

Melanerpes flavifrons*

Veniliornis a. affinis*

Piculus flavigula erythropis*

Piculus polyzonus*

Colaptes melanochloros nattereri

Celeus torquatus tynnunculus*

Celeus f. flavescens*

Celeus flavus subflavus

Dryocopus I. lineatus

\section{Falconiformes}

\section{Falconidae}

Caracara plancus

Milvago c. chimachima

Herpetotheres c. cachinnans

Micrastur r. ruficollis

White-wedged Piculet

White Woodpecker

Yellow-fronted Woodpecker

Red-stained Woodpecker

Yellow-throated Woodpecker

Atlantic Woodpecker

Green-barred Woodpecker

Ringed Woodpecker

Blond-crested Woodpecker

Cream-colored Woodpecker

Lineated Woodpecker

Southern Caracara

Yellow-headed Caracara

Laughing Falcon

Barred Forest-Falcon

Collared Forest-Falcon

American Kestrel

Falco sparverius cearae

Falco rufigularis ophryophanes

Falco peregrinus ssp.

Bat Falcon

Peregrine Falcon

$\begin{array}{ccc}x & x & x \\ x & x & x \\ x & x & x \\ x & & x \\ x & \text { Ifs } & x \\ x & x & x \\ x & x & x \\ x & & x \\ x & & x \\ x & & x \\ x & & x \\ x & & x \\ x & \text { Ifs } & \end{array}$

\section{Psittaciformes}

\section{Psittacidae}

Primolius maracana

Psittacara l. leucophthalmus

Aratinga auricapillus

Eupsittula aurea

Pyrrhura cruentata*

Pyrrhuraf. frontalis*

Pyrrhura leucotis*

Forpus xanthopterygius

Brotogeris tirica*

Touit melanonotus*

Touit surdus*

Pionopsitta pileata*

Pionus m. maximiliani

Amazona rhodocorytha*

\section{Passeriformes}

\section{Thamnophilidae}

Terenura maculata*

Myrmotherula axillaris /uctuosa*

Myrmotherula minor*

Thamnomanes c. caesius*

Rhopias gularis*

Dysithamnus stictothorax*

Dysithamnus m. mentalis*

Dysithamnus plumbeus*

Herpsilochmus rufimarginatus scapularis*

Thamnophilus torquatus

Thamnophilus palliatus vestitus*

Taraba major stagurus

Hypoedaleus guttatus*

Mackenziaena severa*

Myrmoderus loricatus*

Pyriglena leucoptera*

Cercomacrabrasiliana*

Blue-winged Macaw

White-eyed Parakeet

Golden-capped Parakeet

Peach-fronted Parakeet

Ochre-marked Parakeet

Maroon-bellied Parakeet

Maroon-faced Parakeet

Blue-winged Parrotlet

Plain Parakeet

Brown-backed Parrotlet

Golden-tailed Parrotlet

Pileated Parrot

Scaly-headed Parrot

Red-browed Parrot

Streak-capped Antwren White-flanked Antwren

Salvadori's Antwren

Cinereous Antshrike

Star-throated Antwren

Spot-breasted Antvireo

Plain Antvireo

Plumbeous Antvireo

Rufous-winged Antwren

Rufous-winged Antshrike

Chestnut-backed Antshrike

Great Antshrike

Spot-backed Antshrike

Tufted Antshrike

White-bibbed Antbird

White-shouldered Fire-eye

Rio de Janeiro Antbird 


\begin{tabular}{|c|c|c|c|c|c|c|c|}
\hline Taxa & English name & $<500 \mathrm{~m}$ & $>500 \mathrm{~m}$ & $S$ & WA & IUCN & ICMBio \\
\hline Drymophila ferruginea* & Ferruginous Antbird & & $x$ & & $x$ & & \\
\hline Drymophila ochropyga* & Ochre-rumped Antbird & & $x$ & & $\mathrm{x}$ & & \\
\hline Drymophila squamata stictocorypha* & Scaled Antbird & $x$ & $x$ & & $x$ & & \\
\hline \multicolumn{8}{|l|}{ Conopophagidae } \\
\hline Conopophaga I. lineata & Rufous Gnateater & & $x$ & & $x$ & & \\
\hline \multicolumn{8}{|l|}{ Rhinocryptidae } \\
\hline Scytalopus aff. gonzagai* & Boa Nova Tapaculo & & Ifs & & $x$ & & \\
\hline \multicolumn{8}{|l|}{ Grallariidae } \\
\hline Grallaria varia intercedens* & Variegated Antpitta & & $x$ & & $x$ & & \\
\hline \multicolumn{8}{|l|}{ Formicariidae } \\
\hline Formicarius colma ruficeps* & Rufous-capped Antthrush & $x$ & Ifs & & $x$ & & \\
\hline Chamaeza c. campanisona* & Short-tailed Antthrush & & $x$ & & $x$ & & \\
\hline Chamaeza meruloides* & Such's Antthrush & & $x$ & & $x$ & & \\
\hline \multicolumn{8}{|l|}{ Dendrocolaptidae } \\
\hline Dendrocincla turdina* & Plain-winged Woodcreeper & $x$ & $x$ & & $x$ & & \\
\hline Sittasomus griseicapillus olivaceus* & Olivaceous Woodcreeper & $x$ & Ifs & & $x$ & & \\
\hline Xiphorhynchus fuscus tenuirostris* & Lesser Woodcreeper & $x$ & $x$ & & $x$ & & \\
\hline Xiphorhynchus g. guttatus* & Buff-throated Woodcreeper & $x$ & jfp & & $x$ & & \\
\hline Campylorhamphus falcularius* & Black-billed Scythebill & & $x$ & & $x$ & & \\
\hline Campylorhamphus t. trochilirostris* & Red-billed Scythebill & & $x$ & & $x$ & & \\
\hline Lepidocolaptes squamatus* & & & Ifs & & & & \\
\hline Dendrocolaptes platyrostris & Planalto Woodcreeper & $x$ & $x$ & & $x$ & & \\
\hline Xiphocolaptes albicollis bahiae* & White-throated Woodcreeper & $x$ & $x$ & & $x$ & & \\
\hline \multicolumn{8}{|l|}{ Xenopidae } \\
\hline Xenops m. minutus* & Plain Xenops & & $x$ & & $x$ & & \\
\hline Xenops r. rutilans* & Streaked Xenops & $x$ & $x$ & & $x$ & & \\
\hline \multicolumn{8}{|l|}{ Furnariidae } \\
\hline Furnarius f. figulus & Wing-banded Hornero & $x$ & & jfp & $x$ & & \\
\hline Furnarius rufus albogularis & Rufous Hornero & $x$ & & Ifs & & & \\
\hline Lochmias n. nematura & Sharp-tailed Streamcreeper & & $x$ & & & & \\
\hline Automolus I. leucophthalmus* & White-eyed Foliage-gleaner & $x$ & $x$ & & $x$ & & \\
\hline Anabazenops fuscus* & White-collared Foliage-gleaner & & $x$ & & $x$ & & \\
\hline Anabacerthia lichtensteini* & Ochre-breasted Foliage-gleaner & & $x$ & & $x$ & & \\
\hline Philydor atricapillus* & Black-capped Foliage-gleaner & & $x$ & & $x$ & & \\
\hline Heliobletus sp. nov.* & Bahia Treehunter & & $x$ & & $x$ & & \\
\hline Cichlocolaptes I. leucophrus* & Pale-browed Treehunter & $x$ & $x$ & & $x$ & & \\
\hline Pseudoseisura cristata & Caatinga Cacholote & & & & $x$ & & \\
\hline Phacellodomus r. rufifrons & Rufous-fronted Thornbird & $x$ & & Ifs & & & \\
\hline Certhiaxis cinnamomeus russeolus & Yellow-chinned Spinetail & $x$ & & & $\mathrm{x}$ & & \\
\hline Synallaxis cinerea* & Bahia Spinetail & & $x$ & & $x$ & VU & \\
\hline Synallaxis frontalis & Sooty-fronted Spinetail & $x$ & & & $x$ & & \\
\hline Synallaxis spixi & Spix's Spinetail & & $x$ & & $x$ & & \\
\hline Acrobatornis fonsecai* & Pink-legged Graveteiro & $x$ & $x$ & & $\mathrm{x}$ & VU & \\
\hline Cranioleuca pallida* & Pallid Spinetail & & $x$ & & $x$ & & \\
\hline Thripophaga macroura* & Striated Softtail & & $x$ & & $x$ & VU & \\
\hline \multicolumn{8}{|l|}{ Pipridae } \\
\hline Ceratopipra rubrocapilla & Red-headed Manakin & $x$ & $\mathrm{x}$ & & $x$ & & \\
\hline Manacus manacus gutturosus* & White-bearded Manakin & $x$ & $x$ & & $x$ & & \\
\hline Machaeropterus regulus* & Striped Manakin & $x$ & $x$ & & $x$ & & \\
\hline Ilicura militaris* & Pin-tailed Manakin & Ifs & $\mathrm{x}$ & & $x$ & & \\
\hline Chiroxiphia p. pareola & Blue-backed Manakin & & jfp & & & & \\
\hline Chiroxiphia caudata* & Swallow-tailed Manakin & & $x$ & & $x$ & & \\
\hline \multicolumn{8}{|l|}{ Oxyruncidae } \\
\hline Oxyruncus c. cristatus* & Sharpbill & & $\mathrm{x}$ & & $\mathrm{x}$ & & \\
\hline \multicolumn{8}{|l|}{ Onychorhynchidae } \\
\hline Myiobius atricaudus ridgwayi* & & Ifs & & & & & \\
\hline \multicolumn{8}{|l|}{ Tityridae } \\
\hline Schiffornis t. turdina & Trush-like Schiffornis & Ifs & & & & & \\
\hline lodopleura p. pipra* & Buff-throated Purpletuft & Ifs & $x$ & & $x$ & & \\
\hline
\end{tabular}




\begin{tabular}{|c|c|c|c|c|c|c|c|}
\hline Taxa & English name & $<500 \mathrm{~m}$ & $>500 \mathrm{~m}$ & $s$ & WA & IUCN & ICMBio \\
\hline Tityra i. inquisitor & Black-crowned Tityra & $x$ & & & $x$ & & \\
\hline Tityra cayana braziliensis & Black-tailed Tityra & $x$ & jpp & & $x$ & & \\
\hline Pachyramphus v. viridis & Green-backed Becard & $x$ & $x$ & & $x$ & & \\
\hline Pachyramphus c. castaneus* & Chestnut-crowned Becard & & $\mathrm{x}$ & & $\mathrm{x}$ & & \\
\hline Pachyramphus m. marginatus* & Black-capped Becard & $x$ & $x$ & & $x$ & & \\
\hline Pachyramphus v. validus & Crested Becard & & jfp & & & & \\
\hline \multicolumn{8}{|l|}{ Cotingidae } \\
\hline Phibalura flavirostris* & Swallow-tailed Cotinga & & $\mathrm{x}$ & & $x$ & & \\
\hline Pyroderus s. scutatus* & Red-ruffed Fruitcrow & & $x$ & & & & \\
\hline Lipaugus lanioides* & Cinnamon-vented Piha & $x$ & $x$ & & $x$ & & \\
\hline Procnias nudicollis* & Bare-throated Bellbird & $x$ & $x$ & & $x$ & VU & \\
\hline Cotinga maculata* & Banded Cotinga & $x$ & & & $x$ & EN & $C R$ \\
\hline Xipholena atropurpurea* & White-winged Cotinga & $x$ & jfp & & $x$ & EN & VU \\
\hline \multicolumn{8}{|l|}{ Platyrinchidae } \\
\hline Platyrinchus mystaceus cancromus & White-throated Spadebill & $x$ & $x$ & & $x$ & & \\
\hline \multicolumn{8}{|l|}{ Rhynchocyclidae } \\
\hline Mionectes 0 . oleagineus & Ochre-bellied Flycatcher & $\mathrm{x}$ & $x$ & & $x$ & & \\
\hline Leptopogon a. amaurocephalus & Sepia-capped Flycatcher & $x$ & $x$ & & $x$ & & \\
\hline Phylloscartes beckeri* & Bahia Tyrannulet & & $x$ & & $x$ & EN & EN \\
\hline Phylloscartes sylviolus* & Bay-ringed Tyrannulet & & jfp & & & & \\
\hline Rhynchocyclus o. olivaceus & Olivaceous Flatbill & $\mathrm{x}$ & $x$ & & $x$ & & \\
\hline Tolmomyias sulphurescens pallescens & Yellow-olive Flycatcher & & $x$ & & $x$ & & \\
\hline Tolmomyias poliocephalus sclateri & Gray-crowned Flycatcher & $\mathrm{x}$ & jfp & & $x$ & & \\
\hline Tolmomyias f. flaviventris & Yellow-breasted Flycatcher & $x$ & Ifs & & $x$ & & \\
\hline Todirostrum poliocephalum* & Gray-headed Tody-Flycatcher & Ifs & $x$ & & & & \\
\hline Todirostrum cinereum coloreum & Common Tody-Flycatcher & $x$ & & jfp & & & \\
\hline Myiornis auricularis cinereicollis* & Eared Pygmy-Tyrant & $x$ & Ifs & & $x$ & & \\
\hline Hemitriccus diops* & Drab-breasted Pygmy-Tyrant & & $x$ & & $x$ & & \\
\hline Hemitriccus furcatus* & Fork-tailed Pygmy-Tyrant & & $x$ & & $x$ & VU & VU \\
\hline \multicolumn{8}{|l|}{ Tyrannidae } \\
\hline Hirundinea ferruginea bellicosa & Cliff Flycatcher & $x$ & $x$ & & $x$ & & \\
\hline Tyranniscus burmeisteri & Rough-legged Tyrannulet & & $x$ & & $x$ & & \\
\hline Ornithion inerme & White-lored Tyrannulet & $x$ & & & $x$ & & \\
\hline Camptostoma obsoletum cinerascens & Southern Beardless-Tyrannulet & $x$ & $\mathrm{x}$ & & & & \\
\hline Elaenia f. flavogaster & Yellow-bellied Elaenia & $x$ & $x$ & & & & \\
\hline Elaenia spectabilis & Large Elaenia & $x$ & & & & & \\
\hline Elaenia chilensis & Chilean Elaenia & & $x$ & & $x$ & & \\
\hline Elaenia mesoleuca & Olivaceous Elaenia & & $x$ & & & & \\
\hline Myiopagis c. caniceps & Gray Elaenia & $x$ & $x$ & & & & \\
\hline Capsiempis f. flaveola & Yellow Tyrannulet & $x$ & $x$ & & $x$ & & \\
\hline Phyllomyias fasciatus brevirostris* & Planalto Tyrannulet & $x$ & $x$ & & $x$ & & \\
\hline Phyllomyias griseocapilla* & Gray-capped Tyrannulet & & $x$ & & $x$ & & \\
\hline Attila rufus hellmayri* & Gray-hooded Attila & $\mathrm{x}$ & $x$ & & $x$ & & \\
\hline Attila spadiceus uropygiatus* & Bright-rumped Attila & $x$ & jfp & & $x$ & & \\
\hline Legatus I. leucophaius & Piratic Flycatcher & $x$ & $x$ & & & & \\
\hline Ramphotrigon m. megacephalum ${ }^{*}$ & Large-headed Flatbill & & $x$ & & $x$ & & \\
\hline Myiarchus t. tuberculifer & Dusky-capped Flycatcher & $x$ & & & $x$ & & \\
\hline Myiarchus s. swainsoni & Swainson's Flycatcher & & jfp & & & & \\
\hline Myiarchus f. ferox & Short-crested Flycatcher & $x$ & $x$ & & & & \\
\hline Myiarchus tyrannulus bahiae & Brown-crested Flycatcher & & & Ifs & & & \\
\hline Sirystes s. sibilator & Sibilant Sirystes & $x$ & & & $x$ & & \\
\hline Rhytipterna s. simplex* & Grayish Mourner & $x$ & $x$ & & $x$ & & \\
\hline Pitangus sulphuratus maximiliani & Great Kiskadee & $x$ & $x$ & & $x$ & & \\
\hline Philohydor I. lictor & Lesser Kiskadee & $x$ & & & $x$ & & \\
\hline Machetornis r. rixosa & Cattle Tyrant & & & $x$ & & & \\
\hline Myiodynastes maculatus solitarius & Streaked Flycatcher & $x$ & $x$ & & & & \\
\hline Megarynchus p. pitangua & Boat-billed Flycatcher & $x$ & $x$ & & & & \\
\hline Myiozetetes similis pallidiventris & Social Flycatcher & $x$ & $x$ & & $x$ & & \\
\hline Tyrannus melancholicus despotes & Tropical Kingbird & $\mathrm{x}$ & $\mathrm{x}$ & & $\mathrm{x}$ & & \\
\hline
\end{tabular}




\begin{tabular}{|c|c|c|c|c|c|c|c|}
\hline Taxa & English name & $<500 \mathrm{~m}$ & $>500 \mathrm{~m}$ & $S$ & WA & IUCN & ICMBio \\
\hline Empidonomus varius rufinus & Variegated Flycatcher & $x$ & $x$ & & $x$ & & \\
\hline Conopias t. trivirgatus* & Three-striped Flycatcher & Ifs & $x$ & & $x$ & & \\
\hline Colonia c. colonus & Long-tailed Tyrant & & $x$ & & $x$ & & \\
\hline Myiophobus fasciatus flammiceps & Bran-colored Flycatcher & $x$ & $x$ & & & & \\
\hline Fluvicolan. nengeta & Masked Water-Tyrant & $x$ & jfp & & $x$ & & \\
\hline Arundinicola leucocephala & White-headed Marsh Tyrant & & & $x$ & $x$ & & \\
\hline Cnemotriccusf. fuscatus* & Fuscous Flycatcher & & Ifs & & & & \\
\hline Lathrotriccus e. euleri & Euler's Flycatcher & $x$ & $x$ & & $x$ & & \\
\hline Contopus cooperi & Olive-sided Flycatcher & & $x$ & & $x$ & & \\
\hline Contopus c. cinereus* & Tropical Pewee & $x$ & $\mathrm{x}$ & & $x$ & & \\
\hline \multicolumn{8}{|l|}{ Vireonidae } \\
\hline Cyclarhis gujanensis cearensis & Rufous-browed Peppershrike & $x$ & $x$ & & $x$ & & \\
\hline Hylophilus t. thoracicus* & Lemon-chested Greenlet & & $x$ & & $x$ & & \\
\hline Vireo chivi agilis & Chivi Vireo & $x$ & $x$ & & & & \\
\hline \multicolumn{8}{|l|}{ Hirundinidae } \\
\hline Pygochelidon c. cyanoleuca & Blue-and-white Swallow & $\mathrm{x}$ & $x$ & & $x$ & & \\
\hline Stelgidopteryx r. ruficollis & Southern Rough-winged Swallow & $x$ & $x$ & & & & \\
\hline Prognet. tapera & Brown-chested Martin & $x$ & jfp & Ifs & $x$ & & \\
\hline Prognes. subis & Purple Martin & & & & $x$ & & \\
\hline Progne chalybea macrorhamphus & Gray-breasted Martin & $x$ & $x$ & & $x$ & & \\
\hline Tachycineta albiventer & White-winged Swallow & & & $x$ & & & \\
\hline \multicolumn{8}{|l|}{ Troglodytidae } \\
\hline Troglodytes m. musculus & Southern House Wren & $x$ & $x$ & & $x$ & & \\
\hline Campylorhynchus t. turdinus & Thrush-like Wren & $x$ & $x$ & & $x$ & & \\
\hline Pheugopedius g. genibarbis & Moustached Wren & $x$ & $x$ & & $x$ & & \\
\hline \multicolumn{8}{|l|}{ Donacobiidae } \\
\hline Donacobius a. atricapilla & Black-capped Donacobius & $x$ & & jfp & $x$ & & \\
\hline \multicolumn{8}{|l|}{ Polioptilidae } \\
\hline Ramphocaenus m. melanurus* & Long-billed Gnatwren & & $x$ & & & & \\
\hline \multicolumn{8}{|l|}{ Turdidae } \\
\hline Cichlopsis l. leucogenys* & Rufous-brown Solitaire & Ifs & $x$ & & $x$ & & \\
\hline Turdusf. flavipes* & Yellow-legged Thrush & $x$ & $x$ & & $x$ & & \\
\hline Turdus I. leucomelas & Pale-breasted Thrush & $x$ & $x$ & & & & \\
\hline Turdus r. rufiventris & Rufous-bellied Thrush & $x$ & $x$ & & $x$ & & \\
\hline Turdus amaurochalinus & Creamy-bellied Thrush & & $x$ & & & & \\
\hline Turdus albicollis crotopezus* & White-necked Thrush & $x$ & $x$ & & $x$ & & \\
\hline \multicolumn{8}{|l|}{ Mimidae } \\
\hline Mimus saturninus arenaceus & Chalk-browed Mockingbird & & & $\mathrm{x}$ & & & \\
\hline \multicolumn{8}{|l|}{ Passerellidae } \\
\hline Zonotrichia capensis matutina & Rufous-collared Sparrow & $x$ & Ifs & & & & \\
\hline Arremon t. taciturnus & Pectoral Sparrow & $x$ & $x$ & & $x$ & & \\
\hline \multicolumn{8}{|l|}{ Parulidae } \\
\hline Setophaga p. pitiayumi & Tropical Parula & $x$ & $x$ & & & & \\
\hline Setophaga striata & Blackpoll Warbler & & $x$ & & & & \\
\hline Geothlypis aequinoctialis velata & Masked Yellowthroat & & jfp & & & & \\
\hline Basileuterus culicivorus auricapilla & Golden-crowned Warbler & $x$ & $x$ & & $x$ & & \\
\hline Myiothlypis rivularis* & Neotropical River Warbler & Ifs & $\mathrm{x}$ & & & & \\
\hline \multicolumn{8}{|l|}{ Icteridae } \\
\hline Psarocolius d. decumanus & Crested Oropendola & $x$ & jfp & & $x$ & & \\
\hline Cacicus haemorrhous affinis & Red-rumped Cacique & $x$ & $x$ & & $x$ & & \\
\hline Cacicus c. cela & Yellow-rumped Cacique & $x$ & Ifs & & $x$ & & \\
\hline Icterus jamacaii & Campo Troupial & $x$ & & & $x$ & & \\
\hline Gnorimopsar chopi sulcirostris & Chopi Blackbird & Ifs & & $x$ & & & \\
\hline Chrysomus ruficapillus frontalis & Chestnut-capped Blackbird & $x$ & & & & & \\
\hline Molothrus o. oryzivorus & Giant Cowbird & $x$ & & Ifs & $x$ & & \\
\hline Molothrus b. bonariensis & Shiny Cowbird & $x$ & jfp & Ifs & & & \\
\hline Sturnella superciliaris & White-browed Meadowlark & & & $x$ & $x$ & & \\
\hline \multicolumn{8}{|l|}{ Thraupidae } \\
\hline Pipraeidea m. melanonota & Fawn-breasted Tanager & Ifs & $x$ & & $x$ & & \\
\hline
\end{tabular}




\begin{tabular}{|c|c|c|c|c|c|c|c|}
\hline Taxa & English name & $<500 \mathrm{~m}$ & $>500 \mathrm{~m}$ & $S$ & WA & IUCN & ICMBio \\
\hline Cissopis leverianus major & Magpie Tanager & $x$ & $x$ & & $x$ & & \\
\hline Paroaria dominicana & Red-cowled Cardinal & $x$ & & & & & \\
\hline Tangara brasiliensis* & White-bellied Tanager & & & & $x$ & & \\
\hline Tangara cyanomelas* & Silver-breasted Tanager & $x$ & & jfp & $x$ & & \\
\hline Tangara seledon* & Green-headed Tanager & $x$ & $x$ & & $x$ & & \\
\hline Tangara cyanocephala corallina* & Red-necked Tanager & & $x$ & & $x$ & & \\
\hline Tangara s. sayaca & Sayaca Tanager & $x$ & $x$ & & & & \\
\hline Tangara cyanoptera* & Azure-shouldered Tanager & & $x$ & & $x$ & & \\
\hline Tangara p. palmarum & Palm Tanager & $x$ & $x$ & & $x$ & & \\
\hline Tangara ornata* & Golden-chevroned Tanager & Ifs & $x$ & & $x$ & & \\
\hline Tangara cayana flava & Burnished-buff Tanager & $x$ & $x$ & & & & \\
\hline Nemosia pileata caerulea & Hooded Tanager & $x$ & & jfp & & & \\
\hline Conirostrum s. speciosum & Chestnut-vented Conebill & $x$ & Ifs & & & & \\
\hline Sicalis flaveola brasiliensis & Saffron Finch & $x$ & & & $x$ & & \\
\hline Haplospiza unicolor* & Uniform Finch & & $x$ & & $x$ & & \\
\hline Chlorophanes spiza axillaris* & Green Honeycreeper & $x$ & $x$ & & $x$ & & \\
\hline Hemithraupis flavicollis melanoxantha* & Yellow-backed Tanager & $x$ & Ifs & & & & \\
\hline Hemithraupis ruficapilla bahiae* & Rufous-headed Tanager & & $x$ & & $x$ & & \\
\hline Volatiniaj.jacarina & Blue-black Grassquit & $x$ & & Ifs & $x$ & & \\
\hline Coryphospingus pileatus & Pileated Finch & & & jfp & & & \\
\hline Lanio cristatus brunneus & Flame-crested Tanager & $x$ & $x$ & & $x$ & & \\
\hline Tachyphonus rufus & White-lined Tanager & & Ifs & & & & \\
\hline Ramphocelus bresilius dorsalis* & Brazilian Tanager & $x$ & $x$ & Ifs & $x$ & & \\
\hline Tersina v. viridis & Swallow Tanager & $x$ & $x$ & & $x$ & & \\
\hline Cyanerpes cyaneus holti* & Red-legged Honeycreeper & $x$ & $\mathrm{x}$ & & $x$ & & \\
\hline Dacnis nigripes* & Black-legged Dacnis & & $x$ & & $x$ & & \\
\hline Dacnis cayana paraguayensis & Blue Dacnis & $x$ & $x$ & & $x$ & & \\
\hline Coereba flaveola chloropyga & Bananaquit & $x$ & $x$ & & $x$ & & \\
\hline Tiaris fuliginosus & Sooty Grassquit & Ifs & $x$ & & $x$ & & \\
\hline Sporophila frontalis* & Buffy-fronted Seedeater & & $x$ & & $x$ & VU & \\
\hline Sporophila falcirostris* & Temminck's Seedeater & $x$ & $x$ & & $x$ & VU & \\
\hline Sporophila n. nigricollis & Yellow-bellied Seedeater & $x$ & $x$ & & & & \\
\hline Sporophila ardesiaca & Dubois's Seedeater & $x$ & $x$ & & $x$ & & \\
\hline Sporophila c. caerulescens & Double-collared Seedeater & $x$ & jfp & & $x$ & & \\
\hline Sporophila albogularis & White-throated Seedeater & $x$ & & & $x$ & & \\
\hline Sporophila leucoptera cinereola & White-bellied Seedeater & $x$ & jfp & & & & \\
\hline Emberizoides h. herbicola & Wedge-tailed Grass-Finch & & & $x$ & $x$ & & \\
\hline Saltator m. maximus & Buff-throated Saltator & $x$ & $x$ & & $x$ & & \\
\hline Saltator s. similis & & & Ifs & & & & \\
\hline Saltator fuliginosus & Black-throated Grosbeak & & $x$ & & $x$ & & \\
\hline \multicolumn{8}{|l|}{ Cardinalidae } \\
\hline Habia rubica bahiae* & Red-crowned Ant-Tanager & $x$ & $x$ & & $x$ & & \\
\hline Caryothraustes brasiliensis* & Yellow-green Grosbeak & $x$ & $x$ & & $x$ & & \\
\hline \multicolumn{8}{|l|}{ Fringillidae } \\
\hline Euphonia c. chlorotica & Purple-throated Euphonia & $x$ & Ifs & & $x$ & & \\
\hline Euphonia violacea aurantiicollis* & Violaceous Euphonia & $x$ & $x$ & & $x$ & & \\
\hline Euphonia c. cyanocephala & Golden-rumped Euphonia & & $x$ & & $x$ & & \\
\hline Euphonia $x$.xanthogaster* & Orange-bellied Euphonia & $x$ & $x$ & & $x$ & & \\
\hline Euphonia pectoralis* & Chestnut-bellied Euphonia & $x$ & $x$ & & $x$ & & \\
\hline Chlorophonia c. cyanea* & Blue-naped Chlorophonia & & $x$ & & $x$ & & \\
\hline \multicolumn{8}{|l|}{ Passeridae } \\
\hline Passer domesticus & House Sparrow & & Ifs & $x$ & & & \\
\hline
\end{tabular}

